\title{
FAKTOR-FAKTOR PENURUNAN PERTUMBUHAN EKONOMI BATAM
}

\author{
Daris Purba*, Asron Saputra* \\ *Universitas Putera Batam \\ Program Studi Manajemen \\ Jl. Jend. Soeprapto, Batam, Indonesia \\ E-mail: darispurba26@gmail.com
}

\begin{abstract}
Abstrak
Pertumbuhan perekonomian Batam mengalami penurunan beberapa tahun belakangan ini. Sebagai salah satu kawasan bebas Batam seharusnya memiliki pertumbuhan ekonomi yang besar. Penelitian ini mencari semua faktor dari penurunan ekonomi Batam. Data yang digunakan adalah data dari biro statistik dan data-dari dari organisasi seperti Asean. Penelitian ini menemukan bahwa ekonomi Batam yang sangat bergantung kepada Penamanan Modal Asing (PMA) mengalami penurunan pertumbuhan ketika lebih banyak PMA yang keluar daripada yang masuk. Salah satu penyebab utamanya adalah akibat terkena dampak dari berbagai krisis ekonomi dunia sejak tahun 2008. Faktor lainnya adalah kelemahan infrastruktur, muncul banyak pesaing sesame economic zones di kawasan Asean, penerapan tarif masuk ke daerah pabean (yang baru dihapuskan pada awal 2018), upah tenaga kerja yang semakin tinggi setiap tahun, dan tata ruang yang tidak efisien.
\end{abstract}

Kata kunci: PMA, Free Trade Zone, dan Pertumbuhan Ekonomi

\begin{abstract}
Regional economic growth of Batam has been slowing down in the past recent years. As one of biggest economic zones in Asean, Batam is expected to have massive economic growth. This research describes the whole possible factors of economic downturn in Batam. Various sources of data have been used mainly from state statistics bureau and from world organizations like Asean and The UN. We find that FDI is the main contributors of Batam economic activities and is slowing down due to world economic slowdown since US financial crisis in 2008. Other factors are also playing a role in slowing down economic growth such as poor infrastructure, the growth of many economic zones in neighboring countries, protectionist economic policy from central government, rising wages of labors, and ineffective industrial zoning districts.
\end{abstract}

Keywords: FDI, Economic Zones, Batam, and Economic Growth

\section{Pendahuluan}

Laju pertumbuhan ekonomi Kota Batam terus mengalami penurunan beberapa tahun terakhir. Data pada Tabel 1 menunjukkan bahwa pertumbuhan Produk Domestik Regional Bruto (PDRB) Batam selalu mengalami penurunan. Pertumbuhan Kota Batam memang masih di atas pertumbuhan ekonomi nasional namun sebagai kota industri pertumbuhan di bawah $7 \%$ adalah kecil.

TABEL 1

LAJU PERTUMBUHAN EKONOMI BATAM

\begin{tabular}{|l|l|}
\hline Tahun & Laju Pertumbuhan PDRB Kota Batam \\
\hline 2012 & $7,40 \%$ \\
\hline 2013 & $7,18 \%$ \\
\hline 2014 & $7,16 \%$ \\
\hline 2015 & $6,83 \%$ \\
\hline 2016 & $5,45 \%$ \\
\hline
\end{tabular}

Penurunan pertumbuhan ekonomi Batam juga dirasakan di berbagai sektor ekonomi di Batam. Sektor penopang industri adalah yang pertama terkena dampaknya, kemudian menjalar ke sektor retail, properti dan UKM.

Penurunan ekonomi Batam menjadi pembahasan di tingkat nasional. Beberapa koordinasi dilakukan yang berujung pada digantinya para pejabat atas BP Batam pimpinan Hatanto Reksodipoetro. Ini menunjukkan bahwa pemerintah pusat melihat bahwa BP Batam memiliki peranan kunci dalam memajukan ekonomi Batam.

BP Batam tidak sendiri dalam mengelola Batam. BP Batam berbagi kewenangan dengan Pemko Batam. BP Batam lebih fokus kepada pengelolalaan PMA, sementara Pemko fokus kepada penanaman modal berasal dari lokal. Meskipun keduanya memiliki kewenangan yang terpisah, namun dalam prakteknya benturan kewenangan tetap sering terjadi antara 
kedua institusi ini.

Batam merupakan salah satu economic zones yang memfasilitasi kegiatan industri dengan memberikan berbagai kemudahan termasuk juga bebas beberapa pajak.

Enonomic zones banyak berkembang di negaranegara berkembang. Negara-negara berkembang membentuk economic zones adalah dalam rangka menarik PMA. Di ASEAN paling tidak ada sekitar 1600 economic zones dengan berbagai variannya (Asean, 2017). Oleh karena itu, penurunan pertumbuhan di economic zone adalah biasanya disebabkan oleh penurunan pada sisi PMA.

Dengan digantinya pejabat utama BP Batam pmpinan Hatanto Reksodipoetro, berarti pemerintah pusat menganggap bahwa penurunan ekonomi Batam adalah disebabkan pada melemahnya sektor yang dikelola oleh BP Batam, yaitu PMA. Benturan kewenangan telah diupayakan untuk dihilangkan, begitu pula dengan proses perizinan yang panjang sudah diupayakan untuk dipersingkat, walaupun peraturan untuk mensinerjikan keduanya belum juga dibuat.

Segala macam upaya tersebut diharapkan mampu memperbaiki ekonomi Batam, namun masalah tidak hanya ada di soft infrastructure, masalah juga ada pada hard infrastructure khususnya mobilitas barang dan orang.

Batam seharusnya mampu memanfaatkan keunggulan lokasi yang dimilikinya. Batam dan Singapura secara geografis memiliki letak yang sama, yaitu sama-sama di selat Malaka tapi dari sisi pertumbuhan ekonomi Batam kalah jauh dengan Singapura.

Berbagai hal di atas menyebabkan penulis melakukan penelitian dengan judul: "Faktor-faktor Penurunan Pertumbuhan di Batam."

\section{Kajian Literatur}

Pertumbuhan ekonomi suatu daerah dapat diukur melalui Produk Domestik Regional Bruto (PDRB) atau output per kapita. Pertumbuhan terlihat dari meningkatnya konsumsi atau daya beli masyarakat (Mirza, 2012).

Pertumbuhan ekonomi dapat dipengaruhi oleh banyak hal seperti pertumbuhan penduduk, pemerintahan, hubungan internasional, dan sumbersumber kapital baik asing maupun lokal (Lewis, 2006).

Model kawasan economic zones diterapkan di Batam untuk menarik Penanaman Modal Asing (PMA) sebanyak-banyaknya. Namun kenyataannya tidak cukup banyak investor asing yang tertarik malah beberapa tahun belakangan ini beberapa investor asing meninggalkan Batam. Selain dampak dari penurunan harga komoditas dunia, aspek infrastruktur terutama soft infrastructure menjadi faktor utama yang diperparah oleh tumpang tindih kewenangan antara Pemko Batam dan BP Batam. (Muzwardi \& Nurmandi, 2014).

Penerapan economic zone di Batam adalah karena adanya keunggulan kompetitif dari segi geografis yaitu berdekatan dengan Singapura dan Malaysia. Batam juga dinilai memiliki keunggulan kompetitif dari segi ekonomi yaitu tidak pernah mengalami krisis ekonomi, dikenal sebagai sentra elektronik, dan merupakan penyumbang ekspor non migas terbesar kedua setelah Bali (Kuncoro, 2005). Keunggulan kompetitif secara geografis tersebut masih harus ditopang dengan infrastruktur dan kebijakan yang memfasilitasi investasi.

Penelitian terdahulu sebagaimana ditunjukkan dalam Tabel 2 memiliki kesimpulan yang hampir sama bahwa ada ketidaknyamanan investasi di Batam yang disebabkan oleh regulasi pemerintah dan ketidaksiapan infrastruktur. Penelitian ini berbeda karena mencari hal yang paling faktor yang paling dominan berdasarkan prioritas.

TABel 2. Penelitian Terdahulu

\begin{tabular}{|c|c|c|}
\hline Judul Penelitian & $\begin{array}{l}\text { Metode } \\
\text { Analisis }\end{array}$ & Hasil \\
\hline $\begin{array}{l}\text { Special Economic } \\
\text { Zone at the } \\
\text { Crossroads: The Case } \\
\text { of Batam (Aritenang, } \\
\text { Special Economic } \\
\text { Zone at the } \\
\text { Crossroads: The Case } \\
\text { of Batam, 2017) }\end{array}$ & $\begin{array}{l}\text { Deskriptif } \\
\text { Kuantitatif } \\
\text { dengan LQ, } \\
\text { Analisis } \\
\text { Kualiatif } \\
\text { dengan } \\
\text { pendekatan } \\
\text { sejarah }\end{array}$ & $\begin{array}{l}\text { Politisasi ekonomi } \\
\text { dan Institusi yang } \\
\text { rumit memperburuk } \\
\text { kenyamanan } \\
\text { berinvestasi di } \\
\text { Batam }\end{array}$ \\
\hline $\begin{array}{l}\text { Motivasi dan Kendala } \\
\text { Investasi di Batam } \\
\text { (Zaenuddin, 2009)a }\end{array}$ & $\begin{array}{l}\text { Metode } \\
\text { Survei } \\
\text { dengan } \\
\text { Compinience } \\
\text { Sampling }\end{array}$ & $\begin{array}{l}\text { Masalah/kendala } \\
\text { investasi di Batam } \\
\text { antara lain } \\
\text { masalah birokrasi, } \\
\text { ekonomi biaya } \\
\text { tinggi, } \\
\text { perpajakan, } \\
\text { kepabeanan, } \\
\text { keimigrasian, tenaga } \\
\text { kerja, dan masalah } \\
\text { pertanahan. }\end{array}$ \\
\hline $\begin{array}{l}\text { A Comparative Study } \\
\text { On Free Trade Zone: } \\
\text { Development Through } \\
\text { Spatial Economic } \\
\text { Concentration } \\
\text { (Aritenang, } \\
\text { Comparative Study On } \\
\text { Free Trade Zone: } \\
\text { Development Through } \\
\text { Spatial Economic } \\
\text { Concentration, 2009) }\end{array}$ & $\begin{array}{l}\text { Location } \\
\text { Quotient, } \\
\text { Correlation } \\
\text { Analysis, }\end{array}$ & $\begin{array}{l}\text { Lokasi, } \\
\text { infrastruktur, } \\
\text { kebijakan } \\
\text { pemerintah, } \\
\text { mempengaruhi FTZ. }\end{array}$ \\
\hline
\end{tabular}

\section{Metode Penelitian}

Penelitian ini menggunakan analisis kualitatif deskriptif dengan pendekatan perbandingan data. Data tersebut adalah informasi yang diperoleh dari BP Batam melalui wawancara dan BPS Batam melalui publikasi data. Untuk perbandingan maka dibutuhkan data-data dari area economic zones lainnya, penelitian ini hanya membandingkan dengan 
FTZ lain yang terdekat dengan Batam, yaitu Johor Bahru Malaysia.

Creswell (2008) mendefinisikan penelitian kuantitatif sebagai suatu pendekatan atau penelusuran untuk mengeksplorasi dan memahami suatu gejala sentral (Raco, 2010, p. 7). Data berupa data-data angka perekonomian di Batam dan Johor Bahru. Data berupa informasi dari wawancara dengan pejabat BP Batam dan informasi-informasi lainnya dari penelitian-penelitian sebelumnya juga dimasukkan. Data-data tersebut akan diinterpretasi oleh peneliti untuk menghasilkan temuan penelitian.

Masalah dalam penelitian ini adalah penurunan pertumbuhan ekonomi di Batam beberapa tahun terakhir yang sudah menjadi tren. Penelitian ini mencari penurunan tersebut murni disebabkan oleh faktor internal di Batam atau ada pengaruh faktor eksternal. Penelitian ini akan mendiskripsikan kedua penyebab penurunan pertumbuhan ekonomi Batam, baik faktor internal maupun faktor eksternal.

Hipotesis awal adalah bahwa investor asing berpindah dari Batam ke kawasan economi zones di negara lain. Penyebab pindahnya investor tersebut diduga akibat dari kurangnya kenyamanan berinvestasi di Batam; baik dari segi buruknya fasilitas yang disiapkan pemerintah maupun dari segi efisiensi operasional.

\section{Pembahasan}

Pembahasan mengenai sebab-sebab penurunan ekonomi Batam akan dijabarkan satu-persatu berdasarkan urutan prioritas. Pengurutan prioritas ini adalah hasil pengamatan dari pengumpulan informasi dari berbagai sumber. Bebarapa wawancara dengan beberapa ahli dan pihak BP Batam juga menunjukkan bahwa faktor utama penurunan ekonomi Batam adalah karena penurunan ekonomi dunia. Faktor-faktor lain yang dijabarkan setelahnya juga berperan tidak kalah pentingnya yang juga memberi pengaruh terhadap pertumbuhan ekonomi Batam.

Untuk memahami permasalah pertumbuhan ekonomi Batam, terlebih dahulu perlu diketahui karakter ekonomi Batam. Batam adalah kawasan economic zone dengan bentuk FTZ (Free Trade Zone) sekaligus SEZ (Special Economic Zone). Batam adalah kawasan khusus yang didisain untuk menjadi kawasan industri bagi investor asing. Untuk menarik minat investor maka pemerintah membebaskan sejumlah pajak perdangan dan industri.

Berbeda dengan pesaingnya sesama FTZ atau SEZ, struktur investasi di Batam lebih banyak didominasi oleh investasi asing. Industri yang ada di Batam adalah rata-rata milik asing. Hal ini menunjukkan bahwa belum banyak penduduk Indonesia yang melakukan industrialisasi. Indonesia masih belum menjadi negara industri seperti Singapura.

GAMBAR 1

STRUKTUR FDI DI BEBERAPA NEGARA ASEAN TAHUN 2015 (DALAM JUTAAN DOLLAR AS)

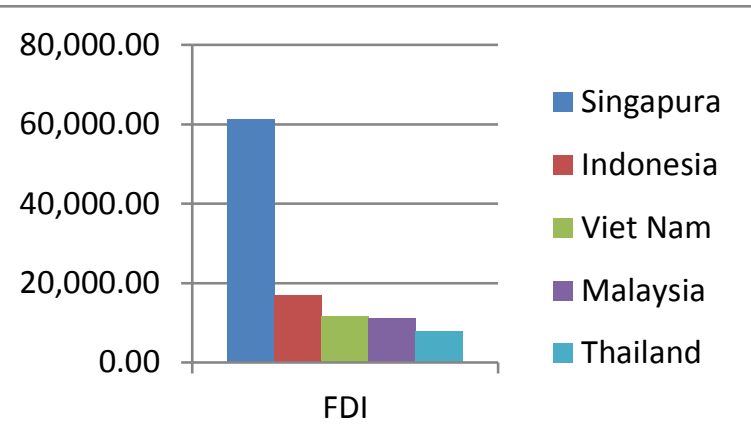

Sumber : ASEAN FDI Statistics Database (Asean, 2016)

Penanaman Modal Asing merupakan salah satu indikator ekonomi, selain pertumbuhan ekonomi. Dalam hal kota Batam, angka realisasi PMA adalah indikator ekonomi utama, penurunan di angka PMA akan mengakibatkan penurunan pada indikatorindikator lainnya.

TABEL 3

INDIKATOR EKONOMI BATAM (JUTAAN US DOLLAR)

\begin{tabular}{|l|l|l|l|l|}
\hline Indikator & $\mathbf{2 0 1 3}$ & $\mathbf{2 0 1 4}$ & $\mathbf{2 0 1 5}$ & $\mathbf{2 0 1 6}$ \\
\hline $\begin{array}{l}\text { Penanaman Modal } \\
\text { Luar Negeri }\end{array}$ & 285.9 & 285.2 & 474.1 & 392.2 \\
\hline $\begin{array}{l}\text { Penanaman Modal } \\
\text { Domestik }\end{array}$ & 75.7 & 20.6 & 34.7 & 20.2 \\
\hline Ekspor & 11.7 & 11.3 & 9.2 & 8.4 \\
\hline Impor & 9.5 & 8.4 & 6.8 & 6.1 \\
\hline
\end{tabular}

Dalam table 2 terlihat komposisi Penanaman Modal Asing di Batam jauh lebih tinggi dari pada Penanaman Modal Domestik, perbandingannya mencapai 4/1 bahkan 14/1 pada tahun 2014.

Ekspor-Impor Batam juga terkena imbasnya yang penurunan per tahunnya secara konsisten berkisar pada angka 1 juta USD.

Angka Impor Batam selalu lebih kecil daripada Ekspor. Hal ini disebabkan perusahaan manufaktur di Batam mengimpor bahan baku, mengolahnya di Batam, lalu menjual semua barang jadi ke luar negeri.

Menurut data yang sudah dirilis BPS, sampai dengan 2016 pertumbuhan ekonomi Batam terus mengalami penurunan (table 1). Pada 2012 pertumbuhan ekonomi Batam pada angka 7,40\% kemudian terus menurun sampai dengan pada tahun 2016 angka pertumbuhan kota Batam menjadi hanya 5,45\%.

GAMBAR 2

STRUKTUR EKONOMI BATAM 


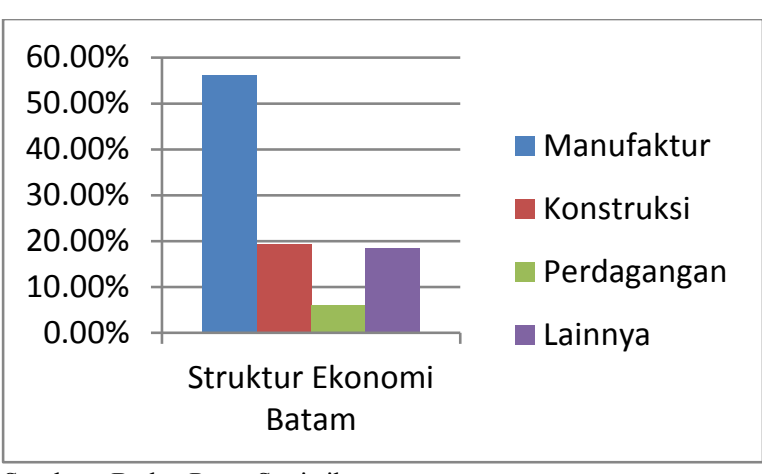

Sumber : Badan Pusat Statistik

Pada gambar 1 terlihat bahwa struktur ekonomi Batam lebih dari 50\% adalah pada sektor manufaktur. Kegiatan manufaktur tersebut didukung oleh kegiatan konstruksi dan perdagangan yang bila ketiganya dijumlah maka menghasilkan $80 \%$ lebih struktur ekonomi Batam.

\section{GAMBAR 3}

NEGARA PMA DI INDONESIA

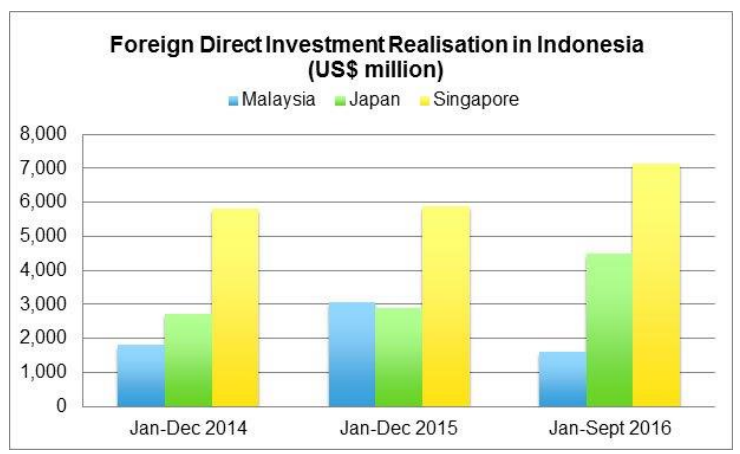

Negara asal investasi asing di Indonesia adalah 50\% lebih berasal dari Singapura. Jepang dan Malaysia dua negara lainnya yang cukup banyak berinvestasi di Indonesia. Hal ini menunjukkan bahwa perusahaan manufaktur di Batam adalah mayoritas milik Singapura mengakibatkan kegiatan perdagangan luar negeri Batam lebih dari setengahnya adalah dengan Singapura.

\section{a. Penurunan Ekonomi Dunia}

Pada satu dekade terakhir, perekonomian dunia terus mengalami berbagai macam goncangan, dimulai dari krisis keuangan global pada tahun 2008-2009, diikuti oleh krisis hutang dalam negeri eropa 2010-2012, dan terakhir adalah krisis harga komoditi global pada 2014 sampai 2016. Pada tahun 2017, ekonomi global mulai membaik dengan pertumbuhan $3 \%$ per tahun, angka tertinggi sejak tahun 2011 (United Nations, 2018).

Harga minyak turun sejak tahun 2015. Penurunan harga minyak ini menyebabkan ketidakseimbangan pada pemasukan perusahaan berbasis perminyakan. Perusahaan yang mensupport perdagangan minyak juga terkena dampaknya.
Laporan dari ASEAN menunjukkan bahwa terdapat penurunan FDI di seluruh kawasan sepanjang tahun 2016 sebesar 97 Miliar USD (Asean, 2017). Hal ini menandakan menurunnya investasi asing di kawasan negara berkembang seperti di Asean.

\section{b. Muncul pesaing}

Pesaing terdekat Batam adalah kawasan Iskandar di Johor Malaysia. Johor tidak didominasi oleh FDI, tapi didominasi oleh investasi lokal. Malaysia merupakan salah satu 3 besar asal PMA di Indonesia. Dengan adanya Iskandar maka dapat mengurangi PMA asal Malaysia karena pindah ke Iskandar.

Johor adalah salah satu area strategis di Malaysia. Daerah ini berbatasan langsung dengan Selat Malaka dan Selat Cina Selatan. Ibukota Johor adalah Johor Bahru. Pada tahun 2000 Johor Bahru mengembangkan pelabuhan peti kemas Tanjung Pelepas. Pada tahun 2006 Johor mengembangkan kawasan FTZ Iskandar Development Region (IDR) yang kemudian berubah nama menjadi Iskandar Malaysia.

Seperti BP Batam, Kawasan Iskandar (IDR) juga memiliki pengelola kawasan, yaitu bernama IRDA (Iskandar Regional Development Authority). Kawasan IDR dirancang untuk pengembangan investasi sampai dengan tahun 2025 (Santoso, 2008).

GAMBAR 4

KAWASAN ISKANDAR MALAYSIA

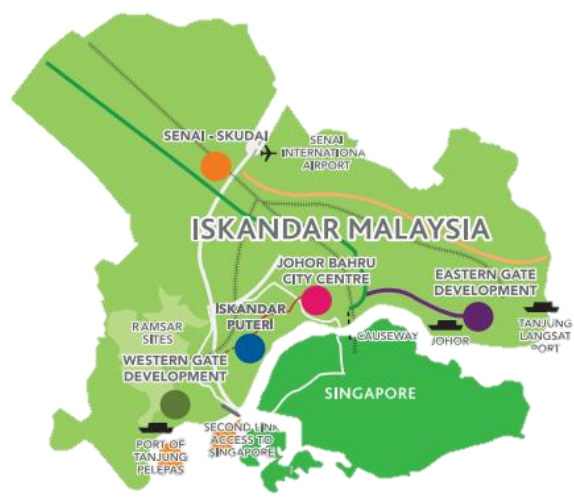

Sumber: IM 10 Years Progres Report

Pertumbuhan investasi kawasan Iskandar dari tahun 2015-2016 sebesar 17\%. Berbeda jauh dengan Batam yang malah mengalami penurunan.

TABEL 4

REALISASI INVESTASI DI KAWASAN FTZ ISKANDAR MALAYSIA (MILIAR RINGGIT) 


\begin{tabular}{|c|c|c|}
\hline Tahun & Nominal & Pertumbuhan \\
\hline 2015 & 98.47 & - \\
\hline 2016 & 119.50 & $21 \%$ \\
\hline 2017 & 140.52 & $17 \%$ \\
\hline
\end{tabular}

Sumber: iskandarmalaysia.com.my

Dilihat dari investor asing di Iskandar Malaysia maka terlihat bahwa ada beberapa negara yang tidak berinvestasi di Batam tapi berinvestasi di Iskandar, seperti China dan Korea Selatan.

\section{GAMBAR 5}

10 NEGARA ASAL FDI Di ISKANDAR MALAYSIA

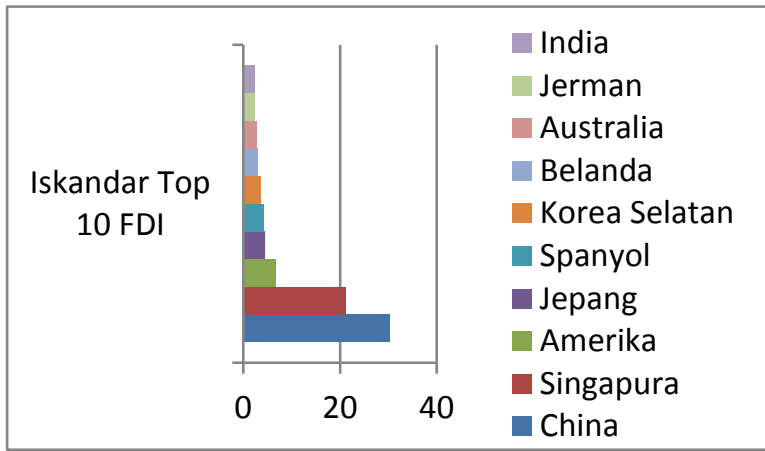

Sumber: iskandarmalaysia.com.my

\section{c. Soft Infrastruktur}

Penelitian yang dilakukan oleh Alberto PortugalPerez dkk., menunjukkan bahwa terdapat hubungan erat antara soft infrastructure terhadap performa export sebuah negara (Portugal-Perez \& Wilson, 2012). Soft infrastructure di sini adalah separangkat set aturan yang menopang kegiatan ekspor, yang menjadi payung hukum dengan penegakan yang baik namun tidak memberatkan.

Regulator di Batam ada dua yaitu BP Batam dan Pemko Batam. Kalau dilihat dari peraturan perundangan maka tidak ada overlapping kewenangan antara dua institusi ini, namun dalam prakteknya di lapangan terjadi tumpang tindih kewenangan.

Tumpang tindih kewenangan itu adalah terutama dalam kewenangan lahan dan penguasaan aset. Sebelum berdirinya pemko Batam, semua lahan dan aset dikuasai oleh BP Batam, namun sejak berdirinya pemko Batam, banyak kewenangan dan aset yang dikuasai oleh BP Batam harus diserahkan kepada Pemko Batam, dalam prakteknya hal tersebut tidak selalu berjalan mulus.

Investor juga merasa direpotkan karena harus menghadapi dua institusi. Parahnya lagi kedua institusi ini seringkali dalam prakteknya saling memveto keputusan satu dengan yang lain. Dualism terjadi dan dirasakan oleh masyarakat dan investor dalam praktek di lapangan meski dalam peraturan perundangan keduanya memiliki wewenang yang berbeda.

Pemko Batam juga dianggap tidak mengurusi Batam dengan baik. Perumahan liar ada di mana-mana, tempat usaha liar dan bangunan liar berdiri di tempat yang sudah diatur untuk dilarang dibangun. Sistem keamanan belum baik. Kriminalitas masih tinggi.

Pimpinan BP Batam ditunjuk oleh pemerintah pusat. Pergantian pimpinan justru menimbulkan konflik baru di kawasan karena pimpinan baru tidak ada hubungan manajemen dengan pimpinan lama. Pimpinan baru juga seringkali tidak menguasai permasalahan Batam.

Seperti pada masa pimpinan BP Batam dialihkan kepada Hatanto Reksodiputro dan tim, selama 10 bulan pertama manajemen baru tidak merealisasikan satu pun permohonan investasi, padahal ada 6000 permohonan investasi yang masuk. Pada masa ini juga terjadi kenaikan UWTO (Uang Wajib Tahunan Otorita) yang dirasakan memberatkan investor (Batam Today, 2016).

\section{d. Hard Infrastruktur}

Pemerintah pusat menginginkan Batam menjadi pusat logistik di daerah regional, pusat bengkel pesawat, industri pariwisata, dan industri digital. Untuk mewujudkannya, BP Batam mengajukan anggaran pembangunan infrastruktur senilai 91,96 Triliun. Infrastruktur yang akan dibangun adalah perluasan bandara dan pelabuhan, pembangunan LRT, pembangunan rumah susun, pembangunan jembatan Batam - Bintan, dan pembangunan air baku. Dengan dana sebesar itu maka diharapkan target pertumbuhan $7 \%$ per tahun akan tercapai (Kusuma, 2018).

Dari besarnya dana yang diminta dapat diketahui bahwa Batam memang kekurangan infrastruktur. Target pertumbuhan ekonomi harus ditunjang dengan pembangunan infrastruktur yang memadai.

\section{e. Tarif Preferensi}

Sebelum terbit Permenkeu No. 229/PMK.04/2017 pada tanggal 29 Desember 2017, barang atau produk hasil industri di Batam dikenakan pajak bea masuk, selain juga pajak pertambahan nilai dan pajak penghasilan. Sehingga untuk mensiasati bea masuk ini, banyak perusahaan di Batam mengirim produknya lewat Singapura karena pajak yang dikenakan lebih kecil (Batam Pos, 2018).

Permenkeu yang berlaku pada akhir Januari 2018 ini telah menghapuskan tarif preferensi untuk produk dari kawasan bebas ke daerah pabean di Indonesia. Hal ini dulu adalah salah satu faktor yang menyulitkan investor yang juga turut andil dalam penurunan PMA di Batam.

\section{f. Biaya Operasional Tinggi}

Salah satu daya tarik investor untuk berinvestasi di 
Indonesia adalah karena upah minimum tenaga kerja yang relatif lebih murah dari banyak negara lain di ASEAN. Upah minimum Indonesia hanya lebih tinggi dari Laos dan Myanmar.

TABEL 5

Perbadingan Upah Minimum Tenaga KeRJa Negara-

NEGARA ASEAN (DALAm Dollar AS)

\begin{tabular}{|l|l|}
\hline \multicolumn{1}{|c|}{ Negara } & \multicolumn{1}{c|}{ Upah Minimum/Bulan } \\
\hline Filipina & $172.58-301.57$ \\
\hline Thailand & $270.71-279.74$ \\
\hline Malaysia & $218.16-237.13$ \\
\hline Vietnam & $147.47-166.57$ \\
\hline Kamboja & 140 \\
\hline Indonesia & $99.91-250.63$ \\
\hline Laos & 110.34 \\
\hline Myanmar & 80.28 \\
\hline Singapura & Tidak ada upah minimum \\
\hline Brunei & Tidak ada upah minimum \\
\hline
\end{tabular}

Sumber: (Pasion, 2017)

UMK Batam pada tahun 2018 adalah sebesar \$243.14, hanya lebih kecil dari Thailand di Asean. Angka itu bahkan lebih besar daripada angka tertinggi UMK di Malaysia yang sebesar \$237.13. Hal menjadi salah satu faktor yang memberatkan investor. Di tengah terpaan resesi perdagangan global, harga minyak dunia turun, revenue perusahaan melemah, maka memberikan upah yang tinggi adalah beban berat bagi perusahaan.

TABEL 6

UMK BATAM

\begin{tabular}{|l|l|l|}
\hline Tahun & UMK \\
\hline & Rupiah & Dollar AS \\
\hline 2012 & Rp1,402,000.00 & $\$ 96.75$ \\
\hline 2013 & Rp2,040,000.00 & $\$ 140.77$ \\
\hline 2014 & Rp2,422,092.00 & $\$ 167.14$ \\
\hline 2015 & Rp2,685,302.00 & $\$ 185.30$ \\
\hline 2016 & Rp2,994,112.00 & $\$ 206.61$ \\
\hline 2017 & Rp3,241,125.00 & $\$ 223.66$ \\
\hline 2018 & Rp3,523,427.00 & $\$ 243.14$ \\
\hline
\end{tabular}

Sumber: (Ete, 2017)

\section{g. Sistem Zonasi Yang Kacau}

Kawasan Pemukiman di Batam selalu mengikuti perkembangan industri. Setiap ada kawasan industri baru, maka akan selalu ada kawasan pemukiman baru di dekatnya. Jalan raya dibuat mengelilingi kawasan industri sekaligus kawasan-kawasan perumahan di sekitarnya (Saputra \& Rachmawati, 2015).

Pengaturan tata ruang yang menempatkan kawasan permukiman penduduk dekat dengan kawasan industri memiliki masalah tersendiri. Penduduk di sekitar kawasan dapat terkena dampak polusi dari industri. Industri juga terganggu dengan kepadatan penduduk di sekitar kawasan terutama di jalur-jalur transportasi.

Perluasan kawasan industri, pelabuhan, bandara, dan jalur-jalur transportasi juga terkendala karena mempertimbangkan keberadaan permukiman di dekatnya. Hal ini mengakitbatkan sulitnya untuk memperbesar kapasitas dan efektifitas kegiatan industri di Batam.

\section{Kesimpulan}

Penurunan PMA di Batam adalah disebabkan karena faktor-faktor berikut ini: (1) Penurunan global arus masuk FDI ke negara-negara berkembang; (2) soft infrastructure yang belum kuat; (3) hard infrastructure yang kurang memadai; (4) munculnya pesaing sesama FTZ di Negara tetangga seperti Malaysia dan Filipina; (5) sulitnya kesempatan untuk masuk pasar Indonesia walaupun sudah beroperasi di Batam; (6) upah tenaga kerja yang semakin tinggi; dan (7) sistem zonasi yang kacau.

\section{Daftar Pustaka}

Aritenang, A. F. (2009). A Comparative Study On Free Trade Zone: Development Through Spatial Economic Concentration. Jurnal Perencanaan Wilayah dan Kota, Vol. 20 No. 2, 95-108.

Aritenang, A. F. (2017). Special Economic Zone at the Crossroads: The Case of Batam. Jurnal Ilmu Sosial dan Ilmu Politik, 132146.

Asean. (2016, 10 5). Foreign Direct Investment Statistics. Retrieved 8 10, 2018, from asean.org:

http://asean.org/?static_post=foreigndirect-investment-statistics

Asean. (2017). Asean Investment Report 2017 Foreign Direct Investment and Economic Zones in Asean. Jakarta: ASEAN and UNCTAD.

Batam Pos. (2018, 1 15). Retrieved 8 11, 2018, from batampos.co.id: https://batampos.co.id/2018/01/15/menke u-hapus-bea-masuk-penjualan-daribatam-ke-daerah-lain/ 
Batam Today. (2016, 10 21). Retrieved 8 11, 2018, from Batamtoday.com: http://m.batamtoday.com/berita-79658Akibat-Kebijakan-Jokowi,-Investasi-diBatam-Jadi-Stagnan-dan-Mundur.html

Ete, S. (2017, 3 6). Retrieved 8 11, 2018, from Koran Perjoeangan: https://www.koranperdjoeangan.com/perk embangan-umk-batam-tahun-1992-2017/

Kusuma, H. (2018, 3 6). Detik Finance. Retrieved 8 11, 2018, from Detik.com: https://finance.detik.com/infrastruktur/d3901416/batam-butuh-rp-91-triliunbangun-7-infrastruktur-termasuk-lrt

Lewis, W. A. (2006). The Theory of Economic Growth. London: Routledge Library Editions.

Pasion, P. (2017, 10 10). Newsbreak. Retrieved 8 11, 2018, from Rappler: https://www.rappler.com/newsbreak/fastfacts/187932-minimum-wage-aseancountries

Portugal-Perez, A., \& Wilson, J. S. (2012). Export Performance and Trade Facilitacion: Hard and Soft Infrastructure. World Development, 1295-1307.

Raco, J. R. (2010). Metode Penelitian Kualitatif: Jenis, Karakteristik, dan Keunggulannya. Jakarta: Grasindo.

Santoso, F. (2008, 11 14). Kompas.com. Retrieved $8 \quad 8, \quad 2018, \quad$ from https://nasional.kompas.com/read/2008/11 /14/0157212/about.html

Saputra, M. A., \& Rachmawati, R. (2015). Perkembangan Kawasan Industri dan Permukiman di Kota Batam tahun 1997 2007. Jurnal Bumi Indonesia, 409-417.

United Nations. (2018). World Economic Situation and Prospects. New York: United Nations Publication.

Zaenuddin, M. (2009). Motivasi dan Kendala Investasi di Batam. Jurnal Politeknik Negeri Batam, 1-12. 